TEME, г. XLIV, бр. 3, јул - септембар 2020, стр. 777-795

Прегледни рад

https://doi.org/10.22190/TEME190110024K

Примљено: 9. 1. 2019.

UDK 37.014.3:323.1

Ревидирана верзија: 18. 3. 2019.

Одобрено за штампу: 1. 10. 2020.

\title{
ЗЛОУПОТРЕБА КОНЦЕПТА УНИФИКАЦИЈЕ ОБРАЗОВАЊА И КРИЗА НАЦИОНАЛНОГ ИДЕНТИТЕТА
}

\author{
Александар Костић*, Срећко Милачић \\ Универзитет у Приштини са привременим седиштем у Косовској \\ Митровици, Економски факултет, Косовска Митровица, Србија \\ *aleksandar.kostic@pr.ac.rs
}

\begin{abstract}
Апстракт
Аутори се у раду баве проблемом образовања, које у својој трансформацији, када су у питању мале земље, подразумева отвореност за некритичко прихватање англосаксонских образовних и културних образаца. Запад је у својој економској надмоћи и својим политичким претензијама успео да уплете савременике у процес трансформације, који, између осталог, подразумева једнообразност у образовању и култури. То омогућава одржавање његове надмоћи. Аутори указују на терминолошку разлику између интернационализације и глобализације образовања. Посебну пажњу посвећују Болоњском процесу у вези са неолибералном стратегијом интеграција, које суштински подразумевају занемаривање националних идентитета. Они критикују комерцијализацију образовања која је у току и, у том контексту, маргинализацију науке о друштву, што води у декаденцију. Етички циљеви се запостављају за рачун апстрактног индивидуализма
\end{abstract}

Кључне речи: образовање, Болоњски процес, унификација национални идентитет, криза.

\section{THE MISUSE OF THE CONCEPT OF THE UNIFICATION OF EDUCATION AND THE NATIONAL IDENTITY CRISIS}

\begin{abstract}
The authors of this paper address the problem of education which in its transformation, when small countries are concerned, means openness towards the uncritical acceptance of Anglo-Saxon educational and cultural norms. Western society, with its economic supremacy and political aspirations, has managed to include contemporaries into the process of transformation, which among other things involves uniformity of education and culture. This enables it to maintain that supremacy. The authors emphasize the difference between internationalization and globalization of education. Special attention is given to the Bologna process in terms of the neoliberal integration strategy which essentially involves the neglect of national identity. They criticize the ongoing commercialization of education and in this sense the marginalization of science in society, which further leads to decadence. Ethical goals are being neglected on account of abstract individualism.

Key words: education, the Bologna process, unification, national identity, crisis.
\end{abstract}


УВОД

Нову етапу на путу развоја човечанства карактерише тенденција уједињавања, као и интернационализација, друштвеног живота. То је сложен и противуречан процес, што се најбоље види у социокултурној сфери, односно у области науке, културе, етике, идеологије и посебно образовања.

Циљ савременог образовања је припрема човека за рад у новим условима светске међузависности, која се огледа у економији, политици, култури, комуникацији итд. Приоритет таквог образовања је изградња наднационалног идентитета. Већ из ове чињенице намеће се питање Шта се у том случају догађа са националним идентитетом?.

Циљ нашег истраживања је да утврдимо како образовање може одговорити на потребу друштва да се створи клима у којој ће припадници различитих етничких група бити свесни свог националног идентитета и слободно развијати осећање припадања заједници у којој живе. Поставља се питање Како принцип коегзистениије и уважавања различитости увести у наставу?. Да ли је мултикултурално образовање решење за тај проблем? Неопходно је разјаснити улогу образовања у развоју мултикултуралности, као и злоупотребу концепта унификације образовања.

Образовање се разматра и као фактор производње који утиче на продуктивност, а такође и на могућност привлачења капитала, развоја конкуренције и стварања радних места. У таквим околностима, оно поприма карактер робе, односно продаје „образовних производа". Болоњска декларација је, између осталог, донета како би помогла раст конкурентне способности образовања у међународним размерама. Супремација тржишне логике над духовношћу и фаворизовање англосаксонске културе постају вредносни оријентири. Која је улога образовања у свему томе? Има ли последица? Наведеним питањима бавимо се у овом раду.

\section{ЗЛОУПОТРЕБА КОНЦЕПТА УНИФИКАЦИЈЕ ОБРАЗОВАЬА}

Крајем XX века започете су промене у различитим областима, које и данас трају. С развојем економске глобализације развија се слободно тржиште, конкуренција и борба за приступ ограниченим сировинским ресурсима. На делу је идеологија која се реализује у интересу богатих и моћних који, захваљујући свом богатству, обликују и политички, медијски и (квази)научни простор. Све то чине како би економску политику довели у позицију да јавно промовише вредности које њима одговарају (Душанић, 2015, стр. 140).

Заједно са економским процесима одвијају се и културни процеси који подразумевају формирање унифициране глобалне културе 
лишене локалних, конфесионалних, националних и етничких разноврсности. Глобализација се са својим изазовима и претњама дотиче националних система образовања стимулишући њихову трансформацију. Пре него што постане субјект модернизације земље, образовање и само мора да се модернизује. То је сложен процес који захтева активно учешће друштва и државе. У том контексту, глобализација образовања подразумева формирање јединственог образовног простора са заједничким основним смерницама и критеријумима. Она је „условљена, пре свега, економским интеграцијама различитих држава и делатношћу транснационалних корпорација, прерасподелом финансијских токова и слободном миграцијом радне снаге" (Марковић, 2008, стр. 39).

Разлике у привредној развијености продубљују јаз између богатих и сиромашних, па и квалитет образовања следи те поделе. На развијеном Западу образоваће се управљачи и будући господари, а у земљама у развоју радна снага за послове у установама и предузећима (Зиновјев, 2002). У таквим околностима стручњаци земаља у развоју нису у стању да прате иновације, што само повећава заостајање ионако заосталих и осиромашених земаља. Развијене земље Запада, посебно САД, преко образовања и васпитања све чине да трансформишу човека на менталном и психолошко-интелектуалном плану. Тако се у Србији оснивају независне образовне институције као што је Београдска отворена школа (БОШ), затим Сорошеви фондови за финансирање „отворених друштава” итд. У Београдској отвореној школи обавезни су модули: Грађанско друштво, ЕУ и Балкан. Концепт за овакве студије је типично амерички. Главне дисциплине су: финансије и берза, реторика, пословна култура итд. Примљени студенти не плаћају школарину (Аврамовић, 2012, стр. 191). Овакво оснивање образовних установа карактеристично је за мале земаље, у том контексту и Србију, те има за циљ промену свести, а самим тим и националног идентитета. Тако:

\begin{abstract}
„Фонд за отворено друштво (Сорош) финансира стручне скупове Министарства, а има и свог члана у Комисији Министарства за акредитацију програма за усавршавање наставника... Разматран је амерички пројекат 'Ја грађанин' (пилот примена) да се у току 2002-2003 реализује у 100 школа у Србији. У раду на овом пројекту радиће Грађанска иницијатива, БОШ, Центар за развој Србије... а превешће се и амерички уџбеник за предмет 'Ја грађанин' (Аврамовић, 2012, стр. 191-192)".
\end{abstract}

Наведено указује на то да постоји отвореност система образовања за утицај англосаксонских образовних и културних образаца. У исто време ради велики број страних образовних институција у Србији:

„Отвара се немачка школа у Београду од првог до десетог разреда. Већ ради International High School Belgrade, а отвара се 
Britanica International School Belgrade, док неке српске високообразовне установе носе имена на енглеском језику IFAM, EUM (EU of International Management and Bussines). Правни факултет у Новом Саду оглашава упис у школу немачког права са предавањима на немачком језику (Грађанско и привредно право Немачке)" (Аврамовић, 2012, стр. 192).

Светска култура, која се намеће заједно са економском доминацијом (Barber, 1995; Castells, 2005), ипак није у стању да тако брзо потисне и расточи национални идентитет. Тако је Furio Cerutti (2001) упоредио формирање идентитета са зидом. Он, наиме, тврди да конструкција идентитета нужно мора да изгради зид којим ће оно властито одвојити од другог и на тај начин постати и туђ. Међутим, то ипак остаје зид, јер отворен идентитет, без зида, према Ћерутијевом мишљењу, противуречи самом себи. Постоје и другачија мишљења. Загорка Голубовић тврди да „где год се изједначава 'ја' са 'ми', а истовремено супротставља 'моје' и 'туђе' (различито) спречава се нормалан процес формирања идентитета" (Голубовић, 2006, стр. 173).

Међутим,

„даровити сами конструишу схватања културних идентитета сопственог, као и других народа, супротстављајући их реализму, тј. оном облику реализма којим се страни редукују на неке од својих аспеката. Ово је у складу са схватањем да разумевање култура, као ни интеркултурна сензитивност, нису независни од когнитивног функционисања, односно имагинативних капацитета људског ума. У постмодерним схватањима све се релативизује, па и сазнања о сопственој култури и културама других народа, а тиме и интеркултурна сензитивност, јер је све подложно замени и ревизији" (Стојановић, Гојков и Гојков Рајић, 2018, стр. 1193-1194).

Све је већа потреба

„за развијање концепције поликултурног васпитања. Ова концепција разматра могућности прилагођавања човека различитим вредностима у ситуацијама различитих култура, узајамно деловање људи са различитим традицијама, оријентацију на дијалог и одрицање од културно-образовног монопола у односима различитих нација” (Јовановић, Качапор, 2016, стр. 355).

Другим речима, свет је све међузависнији. Зато се и заједнички живот учи једнако као и цивилизовано решавање конфликата, солидарност, поштовање и упознавање туђе историје, традиције, па и начина мишљења. Борба против стереотипа често значи рушење заблуда, упознавање нових вредности, окренутост према универзалном. У том смислу је улога образовања у развоју мултикултуралности неопходна. Заобилажење оваквог приступа најчешће води унификацији, херметичности и самодовољности, што није прави начин 
да се идентитет сачува. Напросто, колико год били „отворени”, оно највредније у једном идентитету ће опстати. Вредности одређеног културног идентитета неминовно ће бити препознате од других. Управо то препознавање је и гаранција његовог очувања.

Са друге стране, актуелни су и трендови који произлазе из оквира неолибералног економизма и потрошачког друштва будући да су примарно супротстављени наслеђу, вези прошлости и садашњости и пребогатом културном потенцијалу, који блокира неолибералну праксу и ставља је под сумњу. Њих подржавају и поједини аутори. Тако, Дубравка Стојановић (2010) тврди да је историја преуређена и стављена у нови контекст садашњости, да је у суштини враћен етноцентрични наратив, нација представљена као хомогена целина, а историја као судбина, да су утврђени наративи о пореклу, оснивачима и херојима, слави, жртви, издаји, златном добу итд. Она критикује при томе Завод за издавање уџбеника због монопола и сматра да због тога „настава историје још увек личи на предвојничку обуку" (Стојановић, 2010, стр. 225-227).

У њеном тумачењу проблема занемарује се примордијалистички приступ у одређењу етницитета који инсистира „на претпостављеним крвним везама, фенотипској блискости, језику, религији, етнониму итд." (Формозо, 2009, стр. 298).

Идеал коме би требало да тежи образовање с тачке гледишта националних интереса је моралан човек, патриота, стручњак. Колико одговара образовање таквим захтевима велико је питање јер идеали глобалног друштва које тежи унифицираном образовању су сложени и запостављају националну културу, што представља озбиљну опасност за мале народе. То се односи на нормалну реализацију социокултурне репродукције и преношење основних социјалних вредности на млађа поколења (Запесоцкий, 2002).

Економске интеграције и савремена средства комуникације поставили су два тешка задатка образовању. Прво се тиче тога колико, како и да ли уопште антиципирати у образовним програмима националну државу и национално-државни суверенитет и, друго, како помирити противуречности „између аспеката унификације интеграционих процеса и социокултурне самосвојности националних друштава и регионалних цивилизација" (Галкин, 2002, стр. 10-11).

Противуречности се могу превладати само ако традиционалне институције прихвате изазов и побрину се о асимилацији својих културних пракси у ново информацијско пространство, јер ће их у супротном дуго потискивати сурогати културе, после чега долази до друштвене стагнације и деградације (Начаев, 2004, 31-32). У те институције свакако спада универзитет. Он не би требало да улогу ранијег културног искуства минимизира јер код сваког новог поколења у друштвеном менталитету увек постоје елементи који су продукова- 
ни прошлим поколењима. Зато продирање инокултурних васпитних модела представља озбиљну опасност с тачке гледишта ефикасности социокултурне репродукције (Гершунский, 1998). Другим речима, запостављање или игнорисање духовних темеља националне културе неминовно доводи до дезоријентације друштва. Глобализација образовања у први план ставља идеале индивидуализма и самодовољности. Радни и професионални етос западне цивилизације конституисао се на тим основама. Друштво у транзицији преоријентацијом васпитне делатности на поменуте идеале, уместо да доведе до повећања радне мотивације, доводи до њеног пада. Разлоге за то треба тражити у постојању дискрепанције између прокламоване вредности тржишног концепта преко образовања и онога што се догађа у стварности: експлоатација, повећање криминалитета, пад моралних вредности, пад патриотизма итд. Различити национални и културни идентитети опстају иако је „у борби за егзистенцију Запад сатерао своје савременике до зида и заплео их у мреже своје економске и политичке надмоћи" (Тојнби, 2002, стр. 15-16).

Са развојем процеса глобализације и унификацијом образовања често се повезују појмови као што су „американизација” и „мекдоналдизација”. По мишљењу Џорџа Рицера,

„процес мекдоналдизације је сличан фордизму јер се заснива на хомогеним производима, ригидним технологијама, стандардизованим радним рутинама, деквалификацији и хомогенизацији радника и потрошача" (Рицер, 2009, стр. 191).

Нажалост, када су култура и образовање у питању, мекдоналдизација изазива још веће проблеме, нарочито у земљама у развоју.

„Тежиште се са дубоким предумишљајем помера с изучавања културе, која формира људе с укусом и критичким духом на образовање људи по поруџбини, стварања уских специјалиста потребног нивоа" (Узелац, 2012, стр. 255-256).

То су обично специјалности које су најпотребније развијеним земљама, што је и начин да неразвијене земље и даље остану дубока европска провинција.

„Становништву с ових простора предодређено је необразовање; заборав историјског и културног наслеђа, свест о припадности носиоцима вредности европске цивилизације. То, разуме се, не значи да неће бити никаквог образовања, биће га, по увезеним трећеразредним уџбеницима писаним у европској провинцији.” (Узелац, 2012, стр. 261)

Образовање се данас образлаже квантитативно и, као у Мекдоналдс ресторанима, кроз вулгарни рачун профита. Све се доводи у везу са финансијама, ефикасношћу, приходима и трошковима. Схва- 
тање високог образовања искључиво као инвестиције у људски капитал карактерише образовне политике земаља у развоју широм света. Такво инструменталистичко гледање је редукционистички поглед на свет, а образовање је искључиво у функцији економске машинерије друштва. Међутим, образовање се тиче саме суштине човека и његовог очовечења, друштва и његове структуре. Оно би морало да доприноси расту и развоју личности и да буде усмерено на духовно и интелектуално (Савићевић, 2007, стр. 565-586). Све што смо до сада елаборирали указује на то да „образовање није само процес преноса акумулираних знања, него и васпитања, моралних вредности, културе итд." (Мельникова, 2002, стр. 421).

У том смислу, Ниче истиче да је „задатак образовања: живети и деловати у складу са најплеменитијим тежњама властитог народа" (Ниче, 1997, стр. 126). Проблем националног идентитета и образовања произлази из потребе да се стално преиспитују сопствене културне вредности. У друштвима где постоји плурализам културних вредности и образовних садржаја, национални идентитет и образовање имају за циљ да приближе локалне културе универзалним вредностима. То све није могуће без разумевања глобалних културних процеса. Постављају се нови оријентири за остваривање заједничког културног простора и прихватање нових културних образаца. Такве околности су условиле прихватање Болоњског процеса. Он, у суштини, представља прилагођавање образовања неолибералној стратегији развоја у свету. Карактеристика овог процеса је унификација у области образовања, што је у складу са евроинтеграцијама. Међутим,

,jедно од спорних питања Болоњског процеса је указивање на опасност од угрожавања културне самобитности, унификацијом и стандардизацијом савремене културе, чиме се потискују националне културе, колективни и индивидуални идентитети, хуманистичке вредности и цивилизацијске тековине образовања” (Базић, 2011, стр. 27).

Без уважавања наведених вредности, ерозија морала, патриотизма и, уопште, духовности - повећаваће се.

\section{МОЖЕ ЛИ ОБРАЗОВАЊЕ ПОМИРИТИ РАЗЛИЧИТЕ НАЦИОНАЛНЕ ИДЕНТИТЕТЕ?}

Поставља се питање може ли образовање одговорити на изазове у развијању заједничког идентитета. Деца са различитим националним схватањима, сећањима и нормама долазе у школу и не слутећи да наставници пред собом имају тежак задатак да искуства различитих група мултикултурним приступом развију у заједнички идентитет. У вишенационалној средини покушај да се систематски развија национални идентитет помоћу школе представља облик на- 
метања и, како то Walter Feinberg каже, „симболичког насиља” (Feinberg, 2012, стр. 90). Та врста неосетљивости и насиља према различитим културним праксама је, пре свега, карактеристична за америчко друштво, где се одвајање деце од културе њихових родитеља и замена вредностима доминантног друштва сматра учинком који је добар за децу и поред тога што се она практично без питања одвајају од матерње културе и родитеља. Читаве генерације деце се рано одвајају од родитеља и смештају у ђачке домове, где се уче да буду „Американци”. Овакав вид школе је руковођен идејом да постоји само један облик рационалности.

У либералним друштвима лако се посеже за преобликовањем уверења детета, јер се она сматрају маргиналним, па и примитивним, у односу на праксе јавне школе. Суштина је у томе да либерална теорија културне разлоге претпоставља политичким, што је велики проблем. Формира се отпор у односу на мишљење да школе нису културно неутрална места, односно да нису културно условљене. Критичари оваквих ставова исправно мисле да школе нису и не могу бити неутралне, те да оне најчешће изражавају сопствено гледиште које је одређено културом (Suchman 1993, p. 72). У таквим околностима се проблем кризе националног идентитета са̂м по себи намеће. Требало би да

\begin{abstract}
„национални идентитет и образовање генерички успоставе дијалектички однос између локалних култура, универзалних вредности и глобалних културних процеса. Тиме се превладавају етноцентризам и изолованост, а успостављају конјуктивни односи у којима долази до стварања заједничког културног простора и нових културних образаца” (Базић, 2011, стр. 27).
\end{abstract}

Промене у култури догађају се у оквиру промене система вредности. На делу је неолиберализација образовања (Aronowitz, 2000; Ball, 2012; Canaan and Shumar, 2008; Clarke, 2012; Collini, 2012; Giroux 2014; Ward 2012). Тако је и Болоњски процес везан за неолибералну стратегију, која, између осталог, инсистира на интеграцијама, некритички занемарујући националне идентитете. Спорно је питање колико унификација и стандардизација образовања која се промовише Болоњским процесом угрожава националне културе. Универзитет је укључен у решавање друштвених проблема тако што је претходно и са̂м реформисан. Реформа универзитета подразумева његово прилагођавање тржишној економији. Полако одумире социјална држава, а универзитет постаје један од субјеката неолибералног концепта капитализма којим се човек своди на homo ekonomikusa, а прагматични дух и рационализација све више дехуманизују друштво, па се „образовање и знање растају од васпитања и културе” (Митровић, 2011). У таквим околностима вредносни оријентири не подразумевају избор између различитих могућности, већ се „темеље 
на вредностима доминантне културе" (Трифуновић, 2012, стр. 83). Са друге стране, често понављање митских представа о уједињеној Европи, и то без алтернативе, ствара отпор који се као контрапункт огледа у митологизовању националног идентитета. Тако митологизована свест о Европи „у модерној технологизованој цивилизацији, кристализована огромним бројем понављања у различитим облицима индустријске свести, означава... стављање у сенку сваке аутономије мисли... сваког историјског искуства... сваке човекове храбрости да се служи сопственим разумом" (Ломпар, 2013, стр. 13). Ломпар је имао у виду, између осталог, развијање у образовном процесу представе о потрошачком друштву као најбољем типу социјалне организације, што је у ствари подривање вековне традиције, националне духовности и вредности попут несебичног служења општем интересу.

У околностима англосаксонског културног обрасца, духовни контекст професионализације образовања оријентише се на циљеве и вредности индивидуалног преживљавања. Оно подразумева адаптацију на услове сталне конкуренције. Стрес због угрожености радног места, као и повезаност психолошких стања савременог човека са условима епохе у којој он живи - одавно су примећени. Индивидуални идентитет је угрожен и рађа се потреба за његовом заменом колективним идентитетом. У том контексту, значај нације расте јер она „обезбеђује дом за изгубљене и конфузне” (Bauman, 1997, str. 194).

Са друге стране, примордијалистички приступ у одређењу етницитета изазива подозрење с обзиром на то да глобализација образовања

„омогућава оформљење нове општељудске (информационе) културе која садржи општа убеђења, вредности и принципе и мења стереотипе... ствара нове потребе и духовне вредности" (Тураев, 2002, стр. 35).

На елаборираном контрапункту почивају контроверзе савременог образовања. Оно се тешко ослобађа стереотипа који се „односе на недовољно познавање туђих култура и њихово мерење искључиво аршинима који су резултат само своје културе” (Костић, 2011, стр. 253). Још је 70-их година Хајдегер (Martin Heidegger) указивао на проблем унификације по западном моделу пишући да се савремени глобални дијалог не води између равноправних учесника већ у оквиру језика и концепције искључиво западне цивилизације, што представља потпуну европеизацију планете и човечанства (Heidegger, 1971).

Језик је сама суштина проблема. Енглески језик као преовлађујући приликом изучавања техничких наука не представља толики проблем као при изучавању хуманистичких дисциплина када школовање на нематичном (енглеском) језику апсолутно прети губљењем националног идентитета и културе друштва у целини. Зато је узима- 
ње у обзир национално-културне компоненте код доношења програма образовања насушно потребан (Береговая, 2016, стр. 5). У епохи рађања глобалног језика остаје актуелно питање очувања различитих језика и култура, историјских вредности и традиција (Владимирова, 2016, стр.113-114).

У таквом следу ствари дијалог култура није могућ без компромиса. Мера за интеграције морала би да буде резултат образовања

„које почива на вредностима и које није избацило категорију историцизма... истински класици не потичу из наше културе али их ми доживљавамо као своје. У том смислу јединство Европе требало би да буде свеобухватно... За илустрацију... послужиће нам пример европске књижевности која је састављена од различитих делова, али све су то 'крвна зрнца' која круже једним телом. Ми, наравно, не прејудицирамо целовитост, већ истичемо значај делова. Они нису ништа друго до најбоље вредности идентитета различитих нација... интеграција не подразумева прекид континуитета националних идентитета, већ само есенцијални одабир вредности" (Костић, 2011, стр. 258).

Међутим, данас се често етички циљеви маргинализују за рачун „апстрактног индивидуализма” (Apple, 2012, p. 64). Образовање је сложен процес који не би смео да буде схваћен само као однос пружалаца и корисника услуга, при чему често изостаје контрола одговорности учесника или све нас више одређује „оно што купујемо, а не оно што чинимо" (Apple, 2012, p. 404). У глобализованом свету, сами учесници у образовању најчешће су припадници различитих националних идентитета који су у савременим условима свесни потребе постојања наднационалног идентитета, с тим што би сви добровољно дали свој допринос и прихватили његово ситуирање. Наметање једног културног обрасца као што је англосаксонски по природи ствари изазива отпор са неизвесним резултатом. Образовање би морало да узима у обзир мишљење Освалда Шпенглера, које је изрекао још 1923. године:

„Уместо монотоне слике једнолинијске светске историје... ја видим феномен бројних моћних култура, са првобитном снагом која избија из недара земље која их је створила и за коју су оне строго везане у току целокупног свог постојања и свака од њих се ослања на свој материјал... свој сопствени облик, и свака има своју сопствену идеју, сопствене страсти, сопствени живот, жеље и осећања...” (Шпенглер, 1923, стр. 20).

Све наведено упућује на то да би требало бити обазрив када су у питању национални идентитети и у изградњи новог европског идентитета не заборављати културне вредности различитих народа који су интегрисани у европску заједницу. Образовање, ако буде уважавало различитости, имаће веће шансе за успех. 


\section{КРИЗА КОНЦЕПТА ОБРАЗОВАЬА ИЛИ ОДГОВОР НА ЗАНЕМАРИВАЬЕ НАЦИОНАЛНОГ ИДЕНТИТЕТА}

Чињеница да земље у транзицији теже да у свим сферама што пре достигну развијене земље подразумева интернационализацију образовања. Овај термин је синоним за међународно образовање и уведен је у оптицај са појавом глобализације. Данас се може говорити о тенденцији интернационализације образовања, која је повезана са потребама глобализације економије. Још септембра 2001. године у Паризу одржана је конференција експерата УНЕСКО-а посвећена глобализацији и њеном утицају на високо образовање. Посебна пажња је посвећена квалитету образовања, акредитацијама, признавању квалификација итд. Тада су разграничени појмови интернационализаиије и глобализације. Примећено је да се ова два термина често схватају као синоними иако се они принципијелно разликују. Интернационализација образовања у својој основи претпоставља сарадњу националних структура, укључујући тржишне, док се у исто време као приоритет глобализације јављају наднационални интереси, свеопшта конкуренција, укључујући комерцијализацију, у шта спада и високо образовање, што доводи до прихватања образовања као услуге. Међутим, тешко је претпоставити да ће велике европске земље попут Немачке или Француске са традиционално бесплатним високим образовањем у блиској будућности одлучити да промене уставна решења и престану да гледају на високо образовање као на „друштвено власништво”. Ако се пажљиво прочитају текстови оснивачких докумената у којима су формулисани циљеви и задаци европских земаља у области високог образовања за период до 2010. године, Сорбонски (1998) и Болоњски (1999) у оба документа нигде се директно не говори о глобализацији и комерцијализацији образовања (Ткач, Филиппов и Чистохвалов, 2008, стр. 36).

Међутим, и једно и друго је на делу, с тим што

„цела институција образовања, која ставља акценат на испите, оцењивање, меморисање или бележење чињеница, предано се труди да убије експериментални дух који је од непроцењиве важности у епохи промена. Сем тога, изостављање социолошких сазнања из наставних програма универзитета и средњих школа представља опасну методу којом се обесхрабрује размишљање о најважнијим питањима садашњице” (Манхајм, 2009, стр. 61).

Занемаривање науке о друштву води у декаденцију јер

„необразоване и униформисане масе представљају данас већу опасност по било који поредак него оне класе које имају свесну оријентацију и разумна очекивања" (Манхајм, 2009, стр. 62). 
Централно је питање колико је појединац слободан ако је приморан да прихвати одређене групне вредности. Уколико нема добровољног избора културе, традиције, историје, језика, нема ни слободе. Смисао је у томе да се мора дати право на избор без притисака. Да ли је другачији случај са земљама у транзицији? Нажалост, на делу је осећај инфериорности осиромашених и међусобним зађевицама и ратовима разрушених земаља које су морале да уложе много напора како би прихватиле европску монетарну политику, извршиле реорганизацију законодавства у свим областима, па и у образовању, што подразумева прихватање Болоњског процеса. Са друге стране, „осећај супериорности 'старих' земаља које су успеле да 'извезу' своје оружје, језик и производе широм света" (Турен, 2011, стр. 42) ствара одијум и „оживљава” национални идентитет код малих и сиромашних земаља. У околностима убрзане глобализације и европског уједињавања, земље у транзицији често и несвесно растачу свој национални идентитет, као што смо из претходног поглавља видели - на најгори могући начин, преко образовања.

„У току је стварање Европе без Европљана. Обимност успеха импресионира читав свет; национализам великих европских сила је нестао; сви кажу да су Европљани да не би говорили да су Немци или Италијани... Ако размишљам о сопственој еволуцији, пре свега, запажам слабљење свести о томе да сам Француз. Ја сам волео ову земљу која је била и једина за коју сам од детињства знао и чији језик је уобличио моје емоције и идеје. Био сам истовремено Француз зато што сам ту рођен, али и зато што сам то желео... Да ли ће Европа постати национална држава као што су то биле Енглеска и Француска, да ли ће се ускоро формирати европска свест и европски идентитет и да ли ће се Европљани изјашњавати као такви пре него као Енглези, Немци или Италијани када се буду представљали Американцима или Јапанцима?” (Турен, 2011, стр. 43-44)

Ову Туренову запитаност разуме већина Француза, Енглеза или Италијана јер сваки појединац осећа да му је национални идентитет угрожен. Тако се рађа потреба за одбраном националног идентитета. Французи су, на пример, изгласали Закон о заштити француског језика, што показује да се не односе индиферентно према свом културном идентитету. И у другим европским земљама попут Италије, Шпаније, Грчке итд. јављају се читави покрети који у први план истичу угроженост националног идентитета. Тај проблем не осећају само европске земље. Страх од вестернизације се јавља широм планете, за шта нам могу послужити речи Фарида Закарије, који је записао случајни разговор са једним арапским интелектуалцем:

„Изразио сам разочарење због неспособности влада на Блиском истоку да либерализују своје економије и друштва на 
начин како су то урадили Источноазијци. 'Погледајте Сингапур, Хонгконг и Сеул', рекао сам указујући на њихова изузетна економска достигнућа. Човек - пријатни, шармантни, образовани и прозападни новинар - усправио се и оштро одговорио: 'заиста их погледајте'. Они су напросто имитирали Запад. Њихови градови су јефтине копије Хјустона и Даласа. То може бити у реду за рибарска села, али ми смо наследници једне од великих цивилизација света. Не можемо постати сиромашне четврти Запада" (Закарија, 2004, стр. 129).

Овај осећај поноса живи у многим Европљанима, па и на Балкану. Друштва у транзицији показала су се довољно отвореним да почну некритички да усвајају европске вредности, које се најчешће мере економским аршинима иако ни финансијски ни организационо нису била спремна за различите експерименте и убрзане реформе у образовању. Њихови системи образовања постали су бледа копија образовања Запада и често су попримала карикатуралне облике. Тако се Болоњски процес претвара у „погађање” побуњених студената са руководиоцима факултета око смањивања услова за упис године, школарине и слично. У таквим срединама никоме није падало на памет да подигне глас због, на пример, урушавања националног идентитета. Квазиелите контролишу све, билборди са рекламама „европских“ приватних факултета гротескно изгледају. То су обично сумњиво акредитовани универзитети са огромним бројем студената којима се обећавају европска перспектива и знања. Овај феномен у образовању земаља транзиције узима свој данак и тек ће се показати колико је био погубан. Млади људи постају дезоријентисани, по завршетку таквих универзитета долазе у пренасељене градове у потрази за послом, а већина њих одлази у европске земље, где, уз часне изузетке, обављају послове камионџија, конобара, спасилаца, обезбеђења и слично. Још увек није извршено озбиљно истраживање које би показало колики је проценат младих људи из земаља транзиције запослен у својој струци. Нажалост, из пропагандних разлога новине стално истичу примере стручњака који су успели на Западу. У таквој клими свршени дипломци српских универзитета убрзано уче немачки или неки од скандинавских језика како би лакше нашли посао. Ионако расточени национални идентитет више није парадигма за самоодређење, већ постаје сметња. Ти млади људи обично одлазе да се више не врате. Универзитети отварају одељења са наставом на енглеском језику како би обезбедили студенте и новац за свој опстанак. То је зачарани круг из кога је тешко изаћи.

Утицај таквог образовања на економски раст добро је познат. Финансирање образовања у неолибералним друштвима је

„засновано на широкој процени исплативости улагања, где степен поврата инвестиција обухвата како непосредне еко- 
номске ефекте тако и друштвену добит коју обезбеђује образовање. С друге стране, однос приватних и јавних извора финансирања требало би да грубо одсликава однос јавне и приватне добити које из тога проистичу. У стварности, међутим, однос између јавног и приватног финансирања на свим нивоима и у свим земљама заснован је много више на политичким него на економским факторима" (Трозби, 2012, стр. 175).

Проблем образовања и кризе националних идентитета постоји и у развијенијим друштвима, што само указује на потребу за смисленијом реформом образовања на европском нивоу. Све док се о образовању размишља у категоријама исплативости и неисплативости, проблемом националног идентитета ће се и даље озбиљно бавити социолози, филозофи, етнолози итд. Што је идентитет угроженији по принципу контрапункта, национални идентитет ће бити незаобилазна тема истраживача. Међутим,

„разлике између културних идентитета нису нешто према чему држава треба да се односи неутрално, као што то сматрају заговорници чистих либералних принципа, већ нешто чему се правно-политички идентитет државе мора прилагодити" (Дивјак, 2006, стр. 81).

То је важно нарочито за мултикултурна друштва иако „мултикултурно грађанство може бити извор друштвеног нејединства и унутрашње нестабилности и тако водити растакању земље” (Дивјак, 2006, стр. 83).

Ово је проблем земаља са различитим етничким групама чије се традиционалне културне праксе не уклапају у универзалне принципе либералног поретка, односно више истичу оно што их разликуje, па је на политици да тражи излаз из такве ситуације:

„У политичким миљеима у којима постоји разноврсност културних традиција и идентитета, какви се могу наћи на највећем делу данашњег света, институционалне форме... нису индивидуалистичке институције либеларног друштва већ пре оне политичког и правног плурализма у којима фундаменталне јединице нису појединци већ заједнице... скупине људи које егзистирају са другим скупинама на истој територији или насеобини" (Gray, 1995, str. 136).

Њима се признају културни идентитети, што произлази из конкретних околности. На први поглед, ово изгледа као рационалан аргумент. То није тако јер све произлази из нагодби лидера поменутих културних заједница, што подразумева живот једних поред других и немешање. Групе имају статус изворних носилаца права. Културно-етничка хомогеност и униформност редукује културну комуникацију између различитих група, што је и институционално загарантовано. Ту не може бити речи о толеранцији јер приватна сфера 
није одвојена од јавне. Образовни програми у таквим друштвима најчешће више раздвајају него што спајају и омогућују прожимање различитих културних идентитета.

\section{ЗАКљУЧАК}

Интеграције, уз изазове и претње које доносе, побуђују интересовање научне јавности. Оне се тичу свих сфера живота, нарочито образовања. Оне као сложен процес подразумевају формирање јединственог образовног простора са заједничким основним смерницама и критеријумима. Међутим, то само по себи не значи да ће земље у транзицији, улазећи, на пример, у европске интеграције, решити своје проблеме. У таквим околностима тамо се отварају тзв. Независне образовне институције чији су обавезни модули грађанско друштво, ЕУ итд. Концепт за такве студије је типично амерички. Циљ оваквог освајања образовних установа је својеврсна американизација. Такав след ствари неумитно ствара отпор код људи који држе до свог националног достојанства. Национални идентитет излази из оквира неолибералног економизма и потрошачког друштва, па је често на удару различитих истраживача западне провенијенције. Чак се прибегава тражењу новог дискурса у тумачењу историје. У образовним програмима се најчешће не антиципира национална држава и национално-државни суверенитет. Бојазни да ће без својих културних пракси у новом информацијском пространству преовладати сурогати културе - оправдани су. У том смислу, институције универзитета морале би да буду опрезније приликом антиципирања инокултурних васпитних модела. Образовање се данас образлаже квантитативно као у Мекдоналдс ресторанима кроз вулгарни рачун профита. Све се заснива на приходима и трошковима.

Међутим, „отпор” унификацији у сфери образовања као вид очувања идентитета претпоставља критичку свест, односно формирање људи са критичким духом уместо униформног образовања које ће бринути само о стварању уских специјалиста по поруџбини. У том контексту, прагматични дух и рационализација маргинализују сваку аутономију мисли и историјског искуства. Излаз из такве ситуације требало би потражити у стварању заједничког културног простора где нови културни обрасци неће значити удаљавање образовања и знања од васпитања и културе. За тако нешто веома су битни вредносни оријентири које неће сваки отклон од традиције промовисати у једине и „праве”. До резултата се може доћи само успостављањем дијалога између култура који подразумева компромис. Маргинализација етичких циљева за рачун апстрактног индивидуализма никуда не води. Проблем образовања и кризе идентитета постоји и у развијеним земљама. Наиме, што је културни идентитет угроженији, 
то ће улога образовног програма бити већа. Зато би требало стално трагати за начинима који ће што безболније доводити до прожимања различитих културних идентитета.

\section{ЛИТЕРАТУРА}

Apple, W. М. (2012). Идеологија и курикулум [Ideology and Curriculum]. Београд: Фабрика књига.

Aronowitz, S. (2000). The Knowledge Factory: Dismantling the Corporate University and Creating True Higher Learning. Boston, MA: Beacon Press.

Ball, S.J. (2012). Global Education Inc.: New Policy Networks and the Neo-Liberal Imaginary. London: Routledge.

Barber, B. (1995). Jihad versus McWorld. New York: Times Books.

Bauman, Z. (1997). Postmodernity and its discontents. Cambridge: Polity Press.

Canaan, J. E. and Shumar, W. (2008). Structure and Agency in the Neoliberal University. London: Routledge.

Castells, M. (2002). Das Informationszeitalter II: Die Macht der Identität [The Information Age II: The Power of Identity]. Opladen: Leske + Budrich.

Clarke, M. (2012). The (absent) politics of neoliberal education policy. Critical Studies in Education, 53(3), 297-310.

Collini, S. (2012). What Are Universities For? London: Penguin.

Giroux, H. (2014). Neoliberalism's War on Higher Education. Chicago, IL: Haymarket Books.

Gray, J. (1995). Enlightenment's Wake. London/New York: Routledge.

Kymlicka, W. (1995). Multicultural Citizenship. Oxford: Oxford University Press.

Suchman, L. (1993). Response to Vera and Simon's Situated Action: A Symbolic Interpretation. Cognitive Science 17(1), 71-75.

Ward, S.C. (2012). Neoliberalism and the Global Restructuring of Knowledge and Education. London: Routledge.

Аврамовић, 3. (2012). „Одлив мозгова” из Србије - једно лице глобализације образовања ['Brain drain' in Serbia - One Face of the Globalization of Education]. Социолошки преглед 47(2), 189-202.

Базић, J. (2011). Национални и европски идентитет у Болоњском процесу [National and European Identity in the Bologna Process]. Српска политичка мисао, 33(3), 25-46.

Береговая, О.А. (2016). Глобализачия и развитие непрерывного обазования [Globalization and the Development of Continuing Education], http://elib.sfukras.ru/bitstream/handle/2311/30501/beregovaya_o.a.pdf?sequence=1 3. 1. 2019.

Владимирова, Л.П. (2016). Проблемы обучения иностранным языкам в эпоху глобализации [Problems of Teaching Foreign Languages in an Era of Globalization]. Вестник ПНИПУ. Проблемы языкознания и педагогики 3, 107116, DOI: 10.15593/2224-9389/2016.3.11 https://mgimo.ru/upload/iblock/559/ problemy-obucheniya-inostrannym-yazykam-v-ehpohu-globalizacii.pdf 3. 1. 2019.

Галкин, А. А. (2002). Поступь глобализации и кризис глобализма [The Course of Globalization and Globalization Crisis]. Полития № 2, С. 5-21.

Гершунский, Б. С. (1998). Философия образования для 21. века [Philosophy of Education for the 21st Century]. Москва: Совершенство.

Голубовић, 3. (2006). Поуке и дилеме минулог века: филозофско-антрополошка размишььаға о главним идејама нашег времена [Precepts and Dilemmas of the Past Century: Philosophical and Anthropological Thoughts on Main Ideas of Our Time]. Београд: Филип Вишњић. 
Дивјак, С. (2006). Проблем идентитета: Културно, етничко, национално и индивидуално [The Problem of Identity: Cultural, Ethnical, National and Individual]. Београд: Службени гласник.

Душанић, Б. (2015). Неолиберализам: расправе у Академији економских наука [Neoliberalism: Debates at the Academy of Economic Sciences]. Београд: Catena mundi.

Закарија, Ф. (2004). Будућност слободе: Нелиберална демократија код куће и у свету [The Future of Freedom: Neoliberal Democracy at Home and in the World]. Београд: Дан Граф.

Запесоцкий, А. С. (2002). Гуманитарное образование и проблемы духовной безопасности [Humanistic Education and Problems of Spiritual Safety]. Педагогика № 2, стр. 3-8.

Зиновјев, А. (2002). Запад- феномен западњамтва [West- the Phenomenon of Westernism]. Београд: Наш дом.

Јовановић, Б. и Качапор, С. (2016). Васпитање за међунационалну толеранцију и сарадњу [Education for Inter-ethnic Tolerance and Cooperation]. Теме, 40(1), 351-364.

Костић, А. (2011). Управљање глобализачијом и начионални идентитети (правни и политичко-социолошки аспекти) [Managing Globalization and National Identity (Legal, Political and Sociological Aspects]. http://www.prafak. ni.ac.rs/files/disertacije/Aleksandar_Kostic_Upravljanje_globalizacijom_2011.pdf 29. 12.2018.

Ломпар, М. (2013). Дух самопорищња: прилог критици српске културне политике; У сенци тубинске власти [The Spirit of Self-denial: Annex to the Criric of Serbian Cultural Politics; In the Shadow of Foreign Rule]. Крагујевац: Графостил.

Манхајм, К. (2009). Дијагноза нашег времена [The Diagnosis of our Time]. Нови Сад: Медитеран.

Марковић, Д. Ж. (2008). Глобализаиија и високоиколско образовање [Globalization and Higher Education]. Ниш: МБ Графика.

Мельникова, Н. С. (2002). Глобализация и образование [Globalization and Education], у: В. К. Егорова, Глобализаиия: синергетический подход [Globalization: A Synergistic Approach] (421-425). Москва: РАГС.

Митровић. Љ. Вирус неолиберализма и образовање на платформи Болоњске деклараиије [The Virus of Neoliberalism and Education on the Platform of Bologna Declaration ]. http://www.nspm.rs/kulturna-politika/virus-neoliberalizmai-obrazovanje-na-platformi-bolonjske-deklaracije.html 23.12.2018.

Начаев, В. Я. (2004). Параметри глобализации и факторы Болонского процесса [Indicators of Globalization and Factors of Bologna Process]. Вестн. Моск. ун-ma № 4 C. 27-34.

Ниче, Ф. (1997). О будућности наших образовних установа [On the Future of our Educational Institutions]. Нови Сад: Издавачка књижарница Зорана Стојановића.

Рицер, Џ. (2009). Савремена сочиолошка теорија и ьени класични корени [Contemporary Sociological Theories and its Classical Roots]. Београд: Службени гласник.

Савићевић, Д. М. (2007). Социо-филозофски основи Болоњске декларације [Sociophilosophical foundation of Bologna Declaration]. Педагошка стварност, 53 (7-8), 565-586.

Стојановић, А., Гојков, Г. и Гојков Рајић, А. (2018). Даровити студенти и интеркултурна комуникација [Gifted Students and Intercultural Communitacion]. Теме, 43 (4), 1179-1196. 
Стојановић, Д. (2010). Интерпретација историје и промена система вредности у Србији [Interpretation of History and a Change in the System of Values in Serbia], у: О. Листхауг, С. П. Рамет \& Д. Дулић (Прир.), Грађанске $u$ неграђанске вредности у Србији: Време после Миломевића [Civil and Uncivil Values in Serbia: The Time after Milosevic] (213-233). Нови Сад: Артпринт.

Ткач, Г. Ф., Филиппов, В. М. и Чистохвалов, В. Н. (2008). Тенденции развития и реформы образования в мире [Development and Reform Tendencies of Education in the World]. Москва: РУДН.

Тојнби, А. (2002). Проучавање историје [The Study of History]. Београд: Службени гласник.

Трифуновић, В. (2012). Мултикултурализам и образовање: проблем плурализације идентитета [Multiculturalism and Education: The Problem of Plural Identity]. Српска политичка мисао, 36 (2), 75-92.

Трозби, Д. (2012). Економика културне политике [Economics of Cultural Politics]. Beograd: Clio.

Тураев, В. А. (2002). Глобальные вызовы человечеству [Global Challenges of Humankind]. Москва: Логос.

Турен, А. (2011). Нова парадигма: За боље разумевање савременог света [New Paradigm: For better Understanding of Modern World]. Београд: Службени гласник.

Узелац, М. (2012). Филозофија образовања I. Филозофске основе савремених педагошких теорија [The Philosophy of Education I. Philosophical Foundations of Pedagogic Theory]. Вршац: Висока струковна школа за образовање васпитача.

Фаинберг, В. (2012). Заједничке школе, различити идентитети: национално јединство и културне разлике [Common Schools, Different Identities: National Unity and Cultural Differences]. Београд: Едиција Реч.

Формозо, Б. (2009). Расправе о етницитету [Debates on Entity ]. У: К. Халперн и Ж. Руано-Борбалан (Прир.), Идентитет (u): Појединаи, група, друштво [Identity(s): Individual, group, society] (295-312). Београд: Clio.

Шпенглер, О. (1923). Закат Европы [The End of Europe]. Москва: Книгоиздательство „Берег”.

\title{
THE MISUSE OF THE CONCEPT OF THE UNIFICATION OF EDUCATION AND THE NATIONAL IDENTITY CRISIS
}

\author{
Aleksandar Kostić, Srećko Milačić \\ University in Priština - Kosovska Mitrovica, Faculty of Economics, \\ Kosovska Mitrovica, Serbia
}

\section{Summary}

With the development of economic globalization, the free market, competition is becoming fierce, as well as the fight for the access to limited raw resources. Together with economic processes, cultural processes take place which involve unified education and the development of global culture devoid of local, denominational, national and ethnic diversity. Therefore, globalization, with all its challenges, involves dealing with national educational systems at the same time stimulating their transformation. Such a complex process entails active participation of an entire society and state. The developed Western 
countries, and especially the USA, try to mentally transform people from small countries through education and upbringing. Independent educational institutions are established in small countries. Belgrade Open School (BOS) is founded, Soros funds finance open societies, German school are established, classes in which lectures are received in English and German are formed in schools, etc. A lot of effort is put in an attempt to make young generations neglect their history, tradition, and national importance in order to accept new unified values through ideology incorporated into educational process more easily. This is all derived from neoliberalism and consumerism. Economic integration involves the reconciliation of contradictions such as the unification of integral processes and social and cultural independence. As far as education is concerned, the focus is hesitantly shifted from the study of native culture which does not reject spiritualism towards custom-made education, in other words, creation of highly specialized individuals. It should be taken into consideration that education does not only represent accumulated knowledge, it also incorporates upbringing, moral values, heritage, culture, etc. This implies that we should live in accordance with Nietzsche's view that the task of education is to act in accordance with the noblest aspirations of one nation. However, the Bologna process aims at adjusting education to the neoliberal strategy of social development.

The question arises as to whether or not education can reconcile different national identities. The answer is that it can if any kind of imposition is avoided. In liberal society, people easily resort to the remodeling of child's beliefs. Such an attitude comes from neoliberal theory which presupposes that cultural reasons are political. However, the participants of the educational system often have different national identities, and the imposition of one set of cultural norms, such as the Anglo-Saxon, produces resistance. Spengler who suggests the cultivation of one's ideas, passions, life, wishes and emotions instead of unified education, is on the scent of a solution to the problem. 